\title{
POHANSKÁ PRI PLAVECKOM PODHRADÍ
}

\section{Nové poznatky o hradisku z mladšej a neskorej doby bronzovej ${ }^{1}$}

\author{
J URA J B ARTÍK - R A D OSLAV ČAMBAL - T IBOR LIESKOVSKÝ
}

\begin{abstract}
Pohanská near Plavecké Podhradie. New Information on the Hillfort from the Late Bronze Age. Between 1927 and 1990, the Pohanská hillfort in Plavecké Podhradie was repeatedly surveyed and examined using probes. After 2019, the results of laser scanning provided fundamentally more precise information on the shapes of the terrain and the course of the rampart. As a result of illegal activities, four mass finds were added to the collection: three composed of bronze artefacts and one of gold artefacts. The new finds confirm that the main period of settlement in this site in the Bronze Age was the middle and later Urnfield period, HA2-HB1.
\end{abstract}

Keywords: West Slovakia, Late Bronze Age, hillfort, fortification course, mass finds of bronze, hoard of gold ornaments.

\section{ÚVOD}

Skúmanie územne rozsiahlych archeologických pamiatok, zvlášt hradísk je dlhodobý proces presahujúci život jednej generácie. K malokarpatským exponovaným lokalitám už desatročia vzbudzujúcim záujem bádatelov patrí popri hradnom vrchu nad sútokom Dunaja a Moravy v Bratislave časti Devín a hradnom vrchu v Bratislave aj 495 metrov nad morom vysoký kopec nad obcou Plavecké Podhradie v okrese Malacky.

Prvé písomné zmienky o jeho valovom opevnení sú z 18. storočia, hradisko znovuobjavil v roku 1927 Š. Janšák, ktorý vyhotovil aj prvý plán (obr. 1: A). Už v tridsiatych rokoch minulého storočia doplnilo reálne poznatky o lokalite identifikovanie dvoch hlavných období osídlenia a to na základe zberových nálezov (Eisner 1933, 155, 184; Janšák 1928, 3, obr. 1). V druhej polovici dvadsiateho storočia nasledovali archeologické sondáže rôzneho rozsahu vedené K. Pietom (v roku 1964) J. Paulíkom (v rokoch 1968-1971) a L. Zacharom (v roku 1990).

Ako ukázalo stručné zhrnutie ich výsledkov, $\mathrm{v}$ dobe popolnicových polí sa osídlenie koncentrovalo na najvyššej časti kopca (d’alej akropole). J. Paulík predpokladal, že obyvatelia si tu na umelo upravených terasách postavili nadzemné zrubové stavby na kamenných základoch (archeologickým výskumom sa ich nepodarilo odkryt'). Sondáž v mieste hradby na akropole odkryla deštrukciu $\mathrm{z}$ lomových kameňov a zuholnatených trámov, ktorá bola interpretovaná ako zvyšky valu s drevenou roštovou konštrukciou a čelným kamenným múrom, archeologicky datovaná do stupňa HA2 (Paulík 1971, 31; Tomčíkovál
Paulík 2004, 46). Z dôvodu poškodenia nálezových situácií sa o obytných a hospodárskych objektoch $z$ doby bronzovej usudzuje predovšetkým na základe koncentrácií nálezov identifikovaných vo vrstvách. Väčšiu čast' z nich tvoria fragmenty hlinených nádob priradených predovšetkým čakanskej i velatickej kultúre (prelom stupňov BD/HA1, HA1, HA2). Najmladšia keramika je charakterizovaná ako patriaca velaticko/podolskému horizontu (HA2/HB1), respektíve podolskej kultúre (HB1). Z ostatných nálezov treba vyzdvihnút’ závažia, praslen a hlinené krúžky dokladajúce najskôr textilnú výrobu. Pozostatkom farebnej metalurgie je „kovolejárska dielňa" a zlomky niekol'kých kadlubov z vrstvy. $\mathrm{Na}$ základe výsledkov archeologického výskumu sa konštatovalo, že v porovnaní s ,osadami typu Velem alebo Pobedim“ sú doklady remeselnej výroby na Pohanskej výrazne chudobnejšie a lokalita slúžila v dobe popolnicových polí ako refúgium (Paulík 1971, 31; 1976, 128; Pieta 1971, 5; Tomčíková/Paulík 2006, 73).

$\mathrm{Aj}$ ked' na počiatku 21. storočia sondážne práce v Plaveckom Podhradí nepokračovali, poznatky o lokalite sa vd’aka moderným prospekčným metódam v dvoch oblastiach výrazne doplnili.

\section{NOVÉ POZNATKY O TOPOGRAFII LOKALITY}

Prvou je spresnenie poznania terénnych úprav a priebehu opevnenia na akropole i v celom areáli Pohanskej, pretože dostupné dáta leteckého laserového skenovania (d’alej LLS) umožnili kvalitatívne nové zhodnotenie $\mathrm{v}$ teréne zachova-

\footnotetext{
1 Táto práca bola podporovaná Agentúrou na podporu výskumu a vývoja na základe Zmluvy č. APVV-15-0491. Táto práca bola podporená Vedeckou grantovou agentúrou - projekt VEGA 1/0468/20.
} 
ných reliktov. ${ }^{2}$ Mračno bodov ako produkt LLS je poskytované vo vysokej hustote $20-30$ bodov na $\mathrm{m}^{2}$. Horizontálna presnost' určenia polohy tak dosahuje 2-5 cm a vertikálna 3-10 cm (Leitmannová/Gálovál Michalík 2020). Taká kvalita dát umožňuje generovat’ digitálne modely reliéfu (d’alej DMR) s rozlíšením $25-50 \mathrm{~cm}$ na pixel. Ak by sme mali hodnotit zobrazenia priebehu valov na Pohanskej vyhotovené v priebehu 90 rokov, tak musíme predovšetkým ocenit kvalitu prvého plánu/náčrtu. Štefan Janšák zachytil línie valov zhruba zhodným spôsobom, ako jeho nasledovníci disponujúci neporovnatelne presnejšou technikou a $\mathrm{v}$ porovnaní s volontérom, ktorý archeologické prieskumy vykonával v čase osobného volna aj dostatkom času na realizáciu meraní. Jedinou závažnou odlišnostou je val medzi severným priebehom opevnenia akropoly a vonkajšou fortifikáciou, ktorého existenciu meranie $\mathrm{v}$ šestedesiatych rokoch a vizualizácia DMR zo súčasnosti nepotvrdili. Plány publikované v roku 1928 i v roku 1976 sú ale zatažené spoločným problémom. Zamerania línií valov boli vkreslované do dostupných mapových podkladov, pretože vyhotovenie podrobného polohopisného a výškopisného vrstevnicového plánu členitého priestoru presahujúceho 40 hektárov nebolo v silách, ani finančných možnostiach inštitúcií vykonávajúcich archeologický výskum. Aj tie najpodrobnejšie listy základných mapovaní sa však $\mathrm{v}$ horských zalesnených oblastiach zhotovovali s menšou presnostou a značnou mierou generalizácie. Následkom vkreslovania pomerne presne zameraných priebehov valov do idealizovaných máp dochádzalo $\mathrm{k}$ deformáciám, ktoré vyniknú pri porovnaní s vizualizáciou DMR $\mathrm{s}$ rozlíšením $25 \mathrm{~cm}$ na pixel (tab. I), zvlášt' v oblasti akropoly.

V porovnaní zo staršími plánmi sa na vizualizáci DMR odlišuje predovšetkým tvar vrcholovej plošiny Pohanskej, ohraničenej výraznou svetlou líniou. Neprerušený priebeh tohto navýšenia okrajovej terénnej hrany násypom naznačuje, že umelou fortifikáciou bola chránená celá akropola. Pri jej datovaní dobre poslúžia výsledky výskumov z rokov 1968-1971 či 1990 dokladajúce mladobronzovú aj laténsku fázu výstavby opevnenia. Zaujímavý je obdížnikový útvar na najzápadnejšom, najvyššie položenom vrchole kopca presahujúci priebeh valu. Môžeme iba uvažovat', že obdĺžnik z rozmermi približne 32 × 38 metrov je terénnym reliktom mladšieho, možno stredovekého opevneného objektu. LLS odhalilo d’alšie stopy antropogénneho pôvodu na svahoch pod vrcholovou častou hradiska. Popri do súčasnosti používanom juhovýchodnom chodníku, ktorý označil ako pôvodný prístup na akropolou v Plaveckom Podhradí už Š. Janšák, sa na vizualizácii DMR objavil z opačnej strany kopca d’alší, vytvárajúci na prudkom severnom svahu lomené serpentíny. Iste nie je náhoda, že obidve komunikácie sa strácajú vo vzdialenosti asi $120 \mathrm{~m}$ severne od akropoly, kde sa nachádza výdatný prameň. Chodníky ulahčujúce prístup na vrchol Pohanskej nemôžeme kvôli intenzívnemu laténskemu osídleniu spájat len z dobou bronzovou.

\section{NOVÉ NÁLEZY Z LOKALITY}

Druhou oblastou, v ktorej sa doplnili poznatky o lokalite a jej blízkom zázemí je nálezový fond, ktorý po roku 1990 výrazným spôsobom narástol. Stalo sa to žial' bez účasti archeologických inštitúcií a $\mathrm{v}$ rozpore s platnými zákonmi. Je smutnou realitou, že o aktivitách hl'adačov pokladov vybavených detektormi kovov sa dozvedáme zväčša s časovým odstupom, čo staažuje a niekedy aj úplne znemožňuje spätné overenie pôvodného spôsobu uloženia často unikátnych nálezov. Nižšie prezentované nálezy a súbory boli a niektoré stále sú v držaní piatich subjektov. ${ }^{3}$ Pretože ich čast' už bola zverejnená, pri opise a vyhodnotení sa zameriame na doteraz neznáme. Nálezy môžeme rozdelit na ojedinelé a hromadné. Z hladiska spol’ahlivosti určenia miest nálezu na tie, ktoré identifikoval $\mathrm{v}$ teréne sám nálezca (s presnostou akú mu umožnila pamät) a následne boli pracovníkmi SNM-AM polohopisne a výškopisne zamerané a polohy, o ktorých máme menej určitú, opisnú informáciu.

Dva predmety získané „,v južnej časti hradiska v okolí prameňa" sú uložené $\mathrm{v}$ súkromnej zbierke. Podla informácie boli nájdené spoločne. Prvým je sekera s výrazným zosilňujúcim rebrom na rovnom ústí tulajky a dalším, menej výrazným, len úzkym žliabkom oddeleným pod ním a bez d’alšej výzdoby. Na okraji uško. Prierez klinovitý bez odsadeného ostria s naznačenými bočnými lalokmi (obr. 2: 1). Sekeru priradujeme do skupiny nezdobených, alebo len úsporne zdobených sekier s tulajkou. Podla M. Novotnej sa vyskytujú v dlhom období starších až mladších popolnicových polí (Novotná 1970, 91), zhodné datovanie tejto heterogénnej skupine prisudzujú aj v Rakúsku (Mayer 1977, 187) a na Morave (Ǩíhovský 1992, 195-198). Druhým predmetom je hrot kopije s krátkou, hladkou tulajkou s dvomi protistojacimi otvormi rovnobežnými zo širokým

\footnotetext{
2 Zdroj produktov LLS: ÚGKK SR.

3 Pracovníci SNM-AM k nim získavali prístup v posledných desiatich rokoch a niektorých držitelov presvedčili, aby nálezy odovzdali bezodplatne do verejných zbierok.
} 


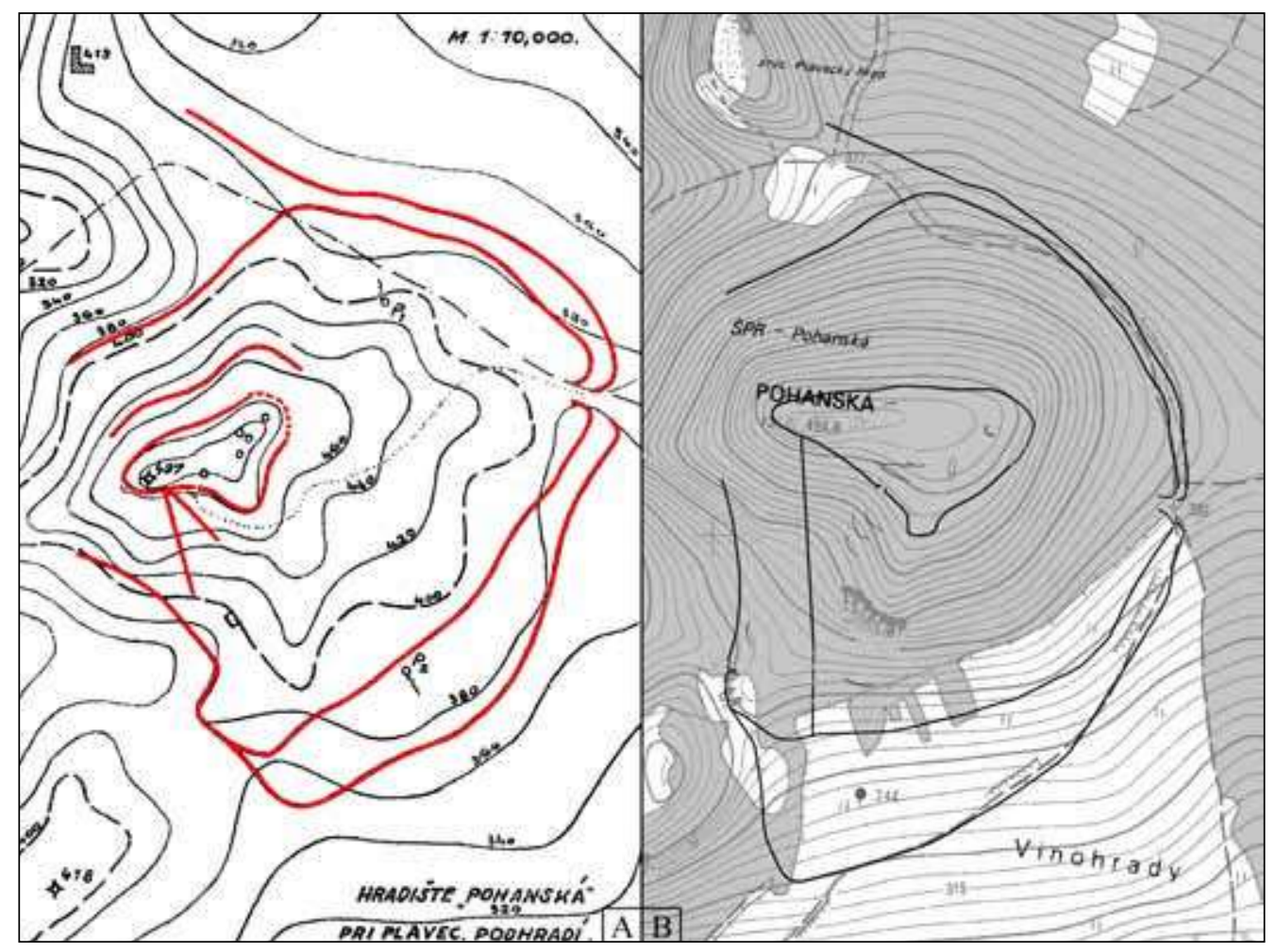

Obr. 1. Plavecké Podhradie-Pohanská. Plány priebehu valov (A - podla Janšák 1928, 3, obr. 1; B - podla Paulík 1976, príloha 2).

listom bez schodíkovitého odsadenia, s najširšou častou $\mathrm{v}$ dolnej tretine. Na liste je pozorovatelný náznak plameňovitého obrysu (obr. 2: 2). Hrot kopije bez výzdoby odpovedá Ř́íhovského skupine hrotov kopijí s hladkým listom a hladkou tulajkou, ktorá sa dalej člení na viaceré varianty. Predmet analogického tvaru s rovným priebehom britov čepele pochádza z depotu z Krumsína patriaceho do horizontu Železné/Křenůvky (HA2/HB1). V prípade, ak náznak plameňovitého obrysu listu nie je výsledkom prebrusovania, hrot môžeme zaradit $\mathrm{k}$ „Variante s volnou krátkou tulajkou kratšou ako polovica celkovej dížky“. Tvarovo identické exempláre z hradiska Kotouč pri Štramberku sú datované na počiatok mladších popolnicových polí (Říhovský 1996, 38, 48).

Ďalší súbor (tab. II: 1-14) odovzdaný do zbierok SNM-AM bol získaný v severnej časti akropoly, jednotlivé predmety boli rozptýlené z vonkajšej i vnútornej strany okrajového valu, železný nákrčník s ukončeniami zahnutými do očka na severnom svahu pod akropolou.

\section{Ihlice}

Horná čast’ bronzovej ihlice s vodorovnými vývalkami členenou gulovitou hlavicou a s nad- stavcom kuželovitého tvaru. Zachovaná čast’ krčku a tela je zdobená vodorovným ryhovaním (tab. II: 2). Z exemplárov publikovaných J. Ř́hovským sú blízke ihlice zo skupiny s dvojkónickou schodíkovite členenou hlavicou a ihlice vodorovne členenou gul'ovitou hlavicou. Ich časový výskyt zahŕňa sporadicky obdobie starších, prevažne však až stredných a mladších popolnicových polí, v neskorých nie sú zastúpené (Ŕhovský 1979, 123, 132). Príbuzné exempláre pochádzajú $\mathrm{z}$ hrobu zo záveru stredných a z počiatku mladších popolnicových polí v Ivanoviciach na Hané (Parma 2004, 433, obr. 10: 5) a zo sídliskovej vrstvy v Zohore (Bobek/Elschek 2020, 38, obr. 2: 2).

Ihlica s hlavicou gulovitého tvaru, prechádzajúceho v hornej časti plynulo do kuželovitého hrotu. Hlavica pokrytá jemne rytou výzdobou pozostávajúcou z obežných vodorovných a šikmých krátkych rýh je s ihlu spojená preliatím (tab. II: 1). Predmet patrí k ihliciam s cibulovitou hlavicou. Ide o typickú industriu mladších popolnicových polí (HB1). Na južnej Morave sa v hroboch vyskytujú spolu s keramikou staršieho stupňa podolskej kultúry, viaceré exempláre s podobnou schémou výzdoby hlavice ako predmet z Plaveckého Podhradia na pohrebisku v Klentnici (Ř́hovský 1979, 186). V severozápadnom Mad’arsku nechýbajú vo väčšom počte $\mathrm{v}$ depote z Románd (Mozsolics 2000, 70, tab. 87: 6-19). 


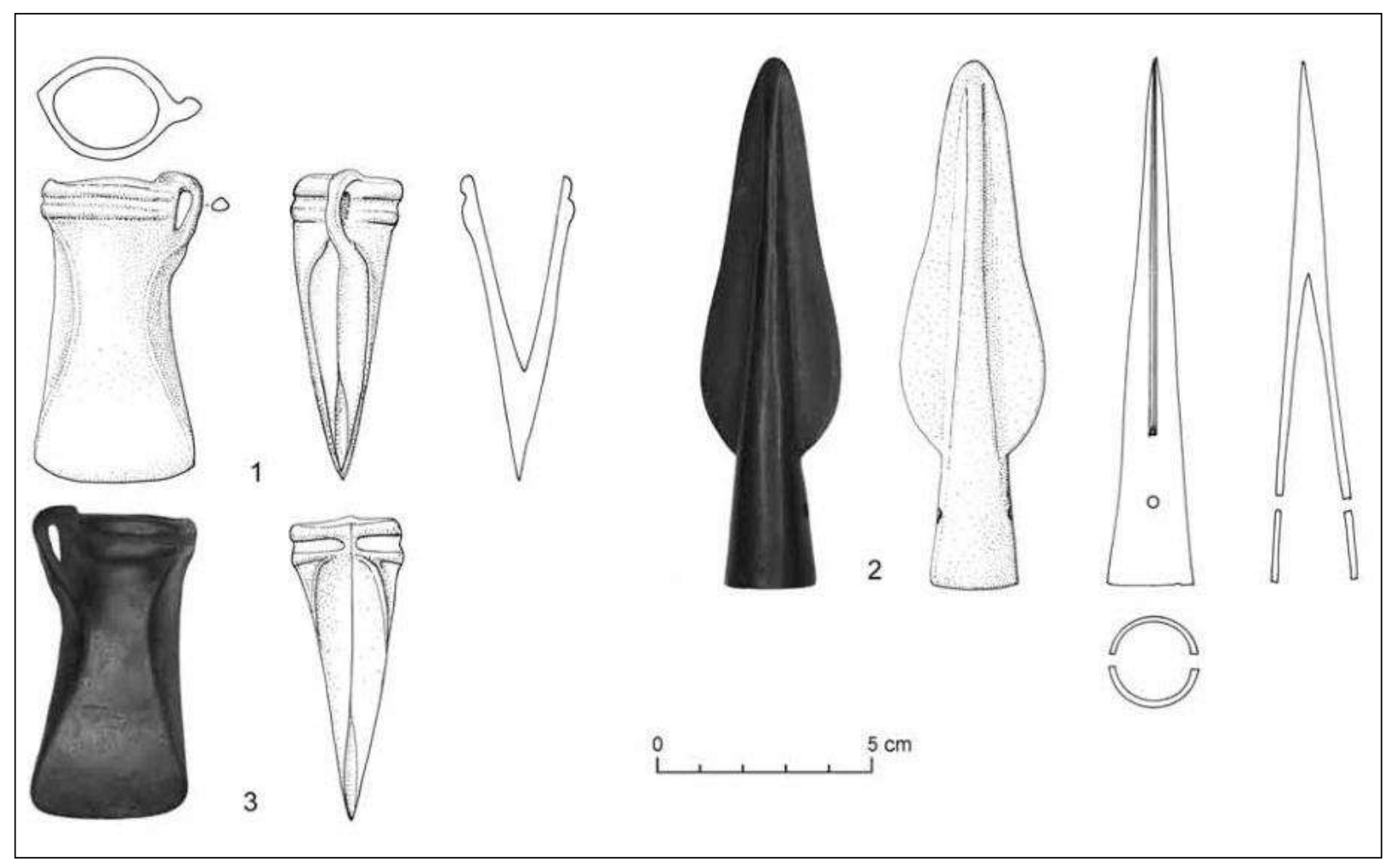

Obr. 2. Plavecké Podhradie-Pohanská. Ojedinelé nálezy.

\section{Nášivky}

Tromi exemplármi sú zastúpené bronzové terčíky opatrené na jednej strane drobným uškom. Odlievané predmety s priemerom $12-15 \mathrm{~mm}$ (tab. II: 3-5) patria k bežným ale málokedy osobitne hodnoteným nálezom bez bližšej vypovedacej hodnoty pre chronológiu. V moravských depotoch sú zastúpené v minimálnych počtoch, ale v dlhom časovom rozpätí starších až neskorých popolnicových polí (Salaš 2005, 117). Desiatky až stovky kusov obsahujú depoty mladších popolnicových polí stupňa Jenišovice v Čechách. V nich sú spolu s dalšími ozdobami pripomínajúcimi garnitúry ozdôb z hrobov žien. Predpokladá sa, že boli prišité na podklad z organickej hmoty a tvorili súčast’ lokálneho kroja (Kytlicová 2007, 79). Ďalšia nášivka/ gombík sa od predchádzajúcich odlišuje väčším záchytným uškom (tab. II: 6). O podobnom exempláre z Kamýku nad Vltavou O. Kytlicová predpokladá, že nebol našitý ale navlečený na remeni (Kytlicová 2007, 79).

\section{Bronzové krúžky}

Zo súboru pochádzajú štyri odlievané krúžky o priemere $20-25 \mathrm{~mm}$, kosoštvorcového až šošov- kovitého prierezu (tab. II: 7-10). Na jeden z nich je navlečené otvorené očko z drôtu (tab. II: 7). Morfologicky navzájom minimálne odlišné krúžky sa sporadicky vyskytujú už v hrobových inventároch a depotoch staršieho i stredného stupňa popolnicových polí, v mladšom stupni ich výskyt masovo narástol. Predpokladá sa, že v kombinácii so šnúrkami či remienkami tvorili súčast’ opaskov, ozdôb tela či konského postroja, prípadne boli našívané na odev (Kytlicová 2007, 89; Salaš 2005, 103).

\section{Hroty šípov}

Tri bronzové hroty šípov zastupujú o dva základné typy. Prvým z nich je hrot trojuholnikového tvaru s náznakom spätných háčikov (tab. II: 12), ktorý predstavuje kombináciou typu D a E pod-

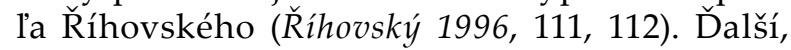
menší má krátke krídelká tvoriace spätné háčiky (tab. II: 11). Druhý typ zastupuje hrot s krídelkami široko rozpätými, ktoré sú výrazne pretiahnuté. Na ústí tulajky je odlomený spätný háčik (tab. II: 13). Hroty šípov je možné zaradit rámcovo do strednej ako aj začiatku mladšej fázy popolnicových polí, čo korešponduje s osídlením lokality v stupňoch HA2-HB1. 


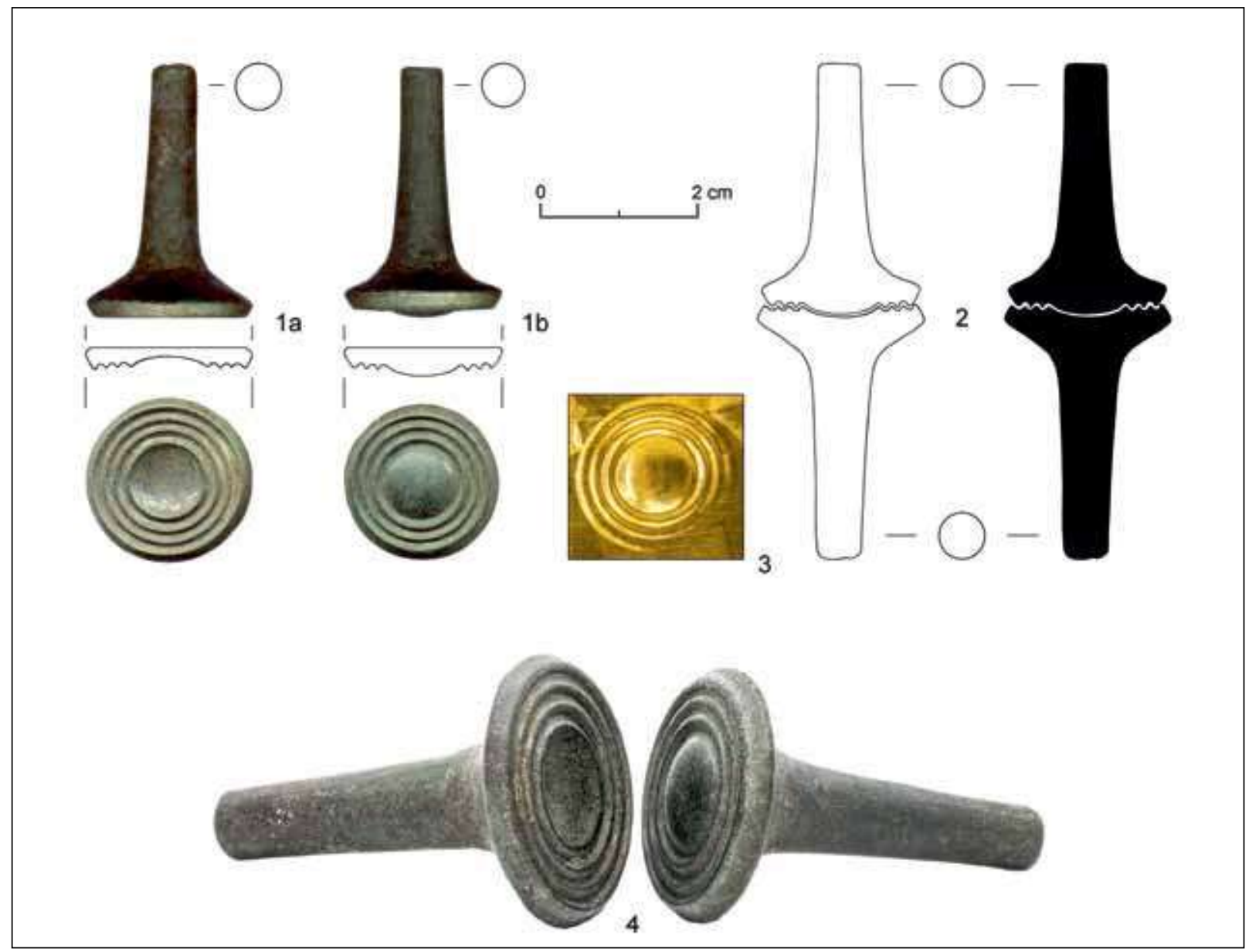

Obr. 3. Plavecké Podhradie-Pohanská. Hromadný nález Plavecké Podhradie III.

\section{Nákrčník zo železa}

Na severnom svahu pod akropolou Pohanskej (tab. I: 4) sa našiel železný nákrčník kosoštvorcového prierezu s ukončeniami zvinutými do očka (tab. III: 14a, b). Analogické predmety z mohylníka z Frögu našli v mohylách č. 72/hrob 1 spolu s harfovitou sponou, č. 80/hrob 1 a pravdepodobne aj v mohyle č. 73 (Tomedi 2002, 193, 194, tab. 50: 3; 51: 1; 58: 3). Tento šperk spájaný s výbavou hrobov žien môžeme pokladat' za prejav doznievania tradície z neskorej doby bronzovej. Datované sú do 2 . fázy pohrebiska, časovo súčasnej so stupňom Ljubljana IIb (Tomedi 2002, obr. 22a) a s HCla podla Ch. Pareho $(2004,542)$. Železný nákrčník podobného tvaru, avšak kruhového prierezu pochádza aj z hrobu A018 na pohrebisku Statzendorf, ktorý je datovaný do HC1 (Rebay 2006, 289, 290, tab. 18: PA38138). Nákrčník pravdepodobne patrí do obdobia záveru neskorých popolnicových polí HB3 a začiatku staršej doby železnej HCla. Z týchto období však na Pohanskej akékolvek nálezy chýbajú. Nie je však vylúčené, že sa môže jednat' o napodobeninu archaického predmetu, ktorý bola vyrobená až v dobe laténskej.

Hromadné nálezy z Pohanskej pri Plaveckom Podhradí označujeme ako Plavecké Podhradie I-IV.

Depot Plavecké Podhradie I (Bartík/Farkaš/Jelínek 2019, 29, 61) odovzdaný do zbierok SNM-AM, bol nájdený na strmom severnom svahu pod akropolou. Miesto nálezu medzi balvanmi (tab. I: 2) bolo spätne zamerané v teréne. Obsahoval bronzové, bohato zdobené náramky (tab. III: 1-7) charakteristické pre obdobie mladších popolnicových polí (HB1).

Depot Plavecké Podhradie II (Bartík/Farkaš/Jelínek 2019, 31) je uložený v Dúbravskom múzeu mestskej časti Bratislava-Dúbravka a čiastočne v súkromnej zbierke. Miesto nálezu na polohe Báborská približne $1,4 \mathrm{~km}$ vzdialené od vrcholu Pohanskej bolo spätne zamerané $\mathrm{v}$ teréne. Pozostáva $\mathrm{z}$ bronzových sekier (tab. IV: 1-4) charakteristických pre obdobie mladších popolnicových polí (HB1).

Súbor Plavecké Podhradie III obsahujúci dvojicu puncov (obr. 3) so sústredenými kruhovými rebierkami na pracovnej ploche (Bartík/Čambal 2018, 115) 
je uložený v zbierkach SNM-AM. Miesto nálezu (tab. I: 1) na severnom svahu pod akropolou bolo spätne zamerané v teréne. Obdobné bronzové punce zo strednej a západnej Európy sú na základe sprievodných nálezov datované do časového intervalu BD-HB2 (Bartík/Čambal 2018, 117-121).

Depot Plavecké Podhradie IV nebol doteraz zverejnený. Držitel'/nálezca ho ponúkol na zdokumentovanie jednému $\mathrm{z}$ autorov príspevku prostredníctvom sociálnej siete. Osobne ukázal miesto na strmom severnom svahu pod akropolou (tab. I: 3), kde skupinu artefaktov "tesne pod povrchom na kôpke našiel". Bod bol spätne zameraný v teréne. Súbor je v súkromných rukách. Hromadný nález obsahoval dve skupiny navzájom prepletených zvitkov zo zlatého drôtu a bronzové krúžky:

1. Trojica navzájom prevlečených špirál vyhotovených $\mathrm{z}$ dvojitého nekonečného drôtu. Na dvoch úplných špirálach je jedno ukončenie nezdobené, druhé ukončenie $\mathrm{v}$ dížke cca $10-12 \mathrm{~cm}$ opatrené pravým tordovaním. Obidve špirály majú po šest' vinutí. $Z$ tretej špirály s odlomenou väčšou častou tordovaného ukončenia sa zachovali štyri vinutia. Materiál je zložený z 82,13-84,01 \% zlata, 14-15,95 \% striebra a 1,93-2,43 \% medi. ${ }^{4}$ Priemer sekundárne deformovaných špirál 4-5,5 cm, hrúbka drôtu 0,67-0,88 mm, spoločná hmotnost' 32,94 g (tab. V: 1b, 2, 9, 10, 12).

2. Trojica navzájom prevlečených špirál vyhotovených z dvojitého nekonečného drôtu. Na dvoch úplných špirálach je jedno ukončenie nezdobené, na druhom sú tordované drôty navzájom spojené a pokračujú plochou rožsirujúcou sa platničkou. Čelné strany obidvoch platničiek pokrýva ornament $z$ križujúcich sa puncovaných línií kombinovaných s prázdnymi plochami kosoštvorcového tvaru (tab. V: 4, 7), ich zadné strany nie sú zdobené. $Z$ rozšírených častí platničiek pokračuje 5 tordovaných drôtov (tab. V:3-5, 7). Tieto časti obidvoch špirál sú značne poškodené. Na zachovalejšej sú tri dvojice oproti sebe postavených terčíkov stvárnených zvinutím drôtu. Filigránske drôtené aplikácie st’ahujú navzájom plechové svorky, ktoré pokrývajú vodorovné puncované línie (tab. V: 8,11$)$. Obidve špirály majú po pät vinutí, tretia, s obidvomi odlomenými ukončeniami štyri vinutia. Materiál je zložený z 84,16-84,9 \% zlata, 12,59-12,87 \% striebra a 2,56-2,97 \% medi. Priemer deformovaných špirál 3-5 cm, hrúbka drôtu 0,71-0,96 mm, spoločná hmotnost' 48,02 g (tab. V: 1b, 2, 3-8, 11).

3. Devät rôzne vel'kých úlomkov tordovaného drôtu, plochá, rozširujúca sa zdobená platnička, z ktorej vychádza dvojica tordovaných drôtov ukončených dvojicou oproti sebe postavených terčíkov z vinutého drôtu, svorka z plechu pokrývajú vodorovné pun- cované línie. Materiál zložený z 84,16-84,9 \% zlata, 12,59-12,87 \% striebra a 2,56-2,97 \% medi. Spoločná hmotnost' 7,01 g (tab. V: 1c).

4. Dva krúžky z tyčinky kosoštvorcového až šošovkovitého prierezu s priemerom $20 \mathrm{~mm}$. Podla nerovnomernej hrúbky tyčinky a švov je zrejmé, že boli zhotovené odliatím. Na vonkajšom obvode sú jemne vrúbkované (tab. II: 15, 16). Materiál bronz.

5. Tri krúžky z tyčinky kosoštvorcového až šošovkovitého prierezu o priemere $13 \mathrm{~mm}$. Na vonkajšom obvode sú jemne vrúbkované. Podla nerovnomernej hrúbky tyčinky je zrejmé, že boli zhotovené odliatím (tab. II: 17-19). Materiál bronz.

Súbor obsahuje dva typy artefaktov zhotovených z exkluzívneho materiálu. Špirály zvinuté z nekonečného dvojitého drôtu s jedným ukončením bez výzdoby a s druhým tordovaným a špirály tej istej konštrukcie, na ktorých sú druhé ukončenia stvárnené šperkárskou technikou pletenia drôtu kombinovanou so zdobenými plechovými svorkami. 11 zlatých fragmentov bolo zjavne súčastou poškodených exemplárov z obidvoch typov špirál.

Jednoduchšie typy špirál z depotu Plavecké Podhradie IV patria k zlatým výrobkom, ktoré nositelia kultúr popolnicových polí používali na širokom teritóriu strednej Európy. Uvažuje sa, že mohli tiež slúžit ako polotovar na d’alšie spracovanie (Bartík 2002, 29; Lehrberger a i. 1997, 170, 177; Stuchlík 2015, 240, obr. 3: 8). $\mathrm{Na}$ ich oblubu a masovú produkciu v mladšej dobe bronzovej poukazuje zvitok zo Zvolena Borovej Hory o hmotnosti 422 g zmotaný z desiatok kusov zlatých špirál z dvojitého drôtu (Malček 2006, 63).

Menej zhodných nálezov nájdeme $\mathrm{k}$ druhému, náročnejšie zdobenému typu ozdôb. Niekedy sú označované podla lokality Várvölgy-Felsözsid na západe Mad’arska, z ktorej pochádza štrnást̉ kusov (Kemenczei 1999, obr. 46; Mozsolics 1981, 299, tab. 13; 14). Ďalší, poškodený, z rakúskeho Bad Aussee (Koppental) a štyri z Bad Goisern (Arikogel) v Rakúsku sú tiež súčastou hromadných nálezov (Gruber 2008, 172, 176, 4.1.7; 4.1.8; 4.2.5). Pretože štyri temer identické predmety zo Sisaku (Sziszek) v Chorvátsku boli zakúpené od starožitníka (Kemenczei 1999, 74, obr. 41; 41a), ich miesto nálezu a pôvodné uloženie $\mathrm{v}$ jednom depote je pravdepodobné, ale nie isté. Pôvod zlatého exempláru s hmotnostou 14,32 g v Libochovanoch v severozápadných Čechách je otázny a okolnosti jeho nálezu neznáme (Lehrberger a i. 1997, 178).

Údaje o hmotnosti súborov obsahujúcich aj iné typy industrie, zlomky a výrobný odpad zo zlata kolíšu medzi Bad Goisern (506 g), nasleduje Várvölgy-Felsözsid (201,42 g) a Bad Aussee (196 g). Depot Plavecké Podhradie IV na základe zastúpenia ozdôb

\footnotetext{
$\overline{4}$ Röntgenovú fluorescenčnú nedeštruktívnu povrchovú analýzu vykonal doc. PhDr. Ján Tirpák, CSc. (Fakulta Prírodných vied UKF v Nitre). Použité zariadenie: ED-XRF (DELTA CLASSIC+, firma OLYMPUS).
} 
typu Várvölgy a špirál z dvojitého nekonečného drôtu do tejto exkluzívnej skupiny hromadných nálezov rozšírených medzi Horným Rakúskom a Chorvátskom plnohodnotne patrí i ked' s menším množstvom (87,91 g) drahého kovu. Hmotnost’ zlatých predmetov zo Sisaku nepoznáme.

Dôležitou otázkou spojenou so zlatými ozdobami typu Várvölgy je ich chronologické postavenie. Pre tento účel sa ukázal byt̉ najvhodnejší súbor z Várvölgy-Felsözsid, ktorého súčastou sú okrem špirál a kruhových fólií zo zlata aj dláto s tulajkou a sekera s tulajkou z bronzu. S ich pomocou ho A. Mozsolicsová zaradila do horizontu depotov typu Germely (Mozsolics 1981, 306) a uvedené datovanie je stále akceptované. Depot Plavecké Podhradie IV je druhým súborom so zlatými ozdobami typu Várvölgy, ktorý okrem artefaktov z cenného kovu obsahuje aj bronzové výrobky (tab. II: 15-19). Tieto sa ale, ako bolo uvedené vyššie $\mathrm{v}$ pasáži o ojedinelých nálezoch bronzových krúžkov $\mathrm{k}$ detailnému datovaniu nehodia.

So zlatými ozdobami typu Várvölgy sú konštrukčne a technikou výroby temer identické ozdoby menších rozmerov vyhotovené z bronzu. Podla aktuálnych vyhodnotení, ich staršia varianta nazvaná podla mad’arskej lokality typ Velem-Szendvid patrí na prelom stupňov HA2/HB1. Centrom rozšírenia „,vlasových krúžkov s pseudoosmičkovým ukončením" je východoalpský priestor severného Chorvátska, Slovinska a západného Mad’arska, niekol'ko ich preniklo do mad’arského Zadunajska, na západné Slovensko a na Moravu. K variante Velem-Szendvid boli priradené aj zlaté exempláre z Várvölgy-Felsözsid a Bad Goisern (Pabst 2013, 34, 47, obr. 8). Pre absolútne datovanie ozdôb typu Várvölgy je obzvlášt dôležitý dôkladne vyhodnotený neštandardný pohreb nespáleného tela zo sídliskovej jamy v Ivanoviciach na Hané. Súčastou mimoriadne bohatej garnitúry ženských ozdôb je aj poškodený šperk odpovedajúci ozdobám typu Velem-Szendvid. Výsledky absolútneho datovania rádiokarbonovou metódou poskytli s $95 \%$ pravdepodobnostou časový interval 1051-908 cal. BC (Parma a kol. 2017, 285). Uvedený časový úsek je v súlade so súčasným názorom na postavenie skupiny depotov typu Gyermely, ktoré ukladali do zeme aj v mladšom stupni popolnicových polí (Hansen 1994, 397), čiže v stupni HB1.

O spôsobe nosenia zlatých ozdôb typu Várvölgy i bronzových typu Velem-Szendvid nepanuje jednotný názor. Označované sú ako nákrčníky (Kemenczei 1999, 74; Mozsolics 1981, 299; Novotná 1984, 47), náramky (Gruber 2008, 174) i ozdoba vlasov (Pabst 2013, 34). Napriek tomu, že predmety z Pla- veckého Podhradia IV sú temer úplné, neposkytujú $\mathrm{v}$ tejto oblasti jednoznačnú odpoved'. Pružný drôt z ktorého sú vyhotovené má dostatočnú dližku, aby sa stočený do špirály s viacerými vinutiami a teda menším priemerom dal nosit na zápästí či člen$\mathrm{ku}$, alebo rozvinutý na hrdle. Preto sa pridŕžame neutrálneho termínu „ozdoby“.

\section{ZÁVER}

Na základe vyššie uvedeného, môžeme zhrnút súčasné poznatky o osídlení Pohanskej pri Plaveckom Podhradí v priebehu mladšej a neskorej doby bronzovej do nasledujúcich bodov:

1. Spresnili sa poznatky o priebehu valov a o topografii lokality. Opevnenie akropoly chránilo plochu 3,92 ha, na severnom svahu pod akropolou sa identifikoval zaniknutý chodník smerujúci k prameňu.

2. Záver urobený po realizácii archeologických výskumov, že osídlenie nositelov popolnicových polí na lokalite nebolo z hladiska nálezov intenzívne a z lokality pochádza málo dokladov remeselno výrobného charakteru ostáva v platnosti. Odovzdaný súbor (tab. II: 1-13) vzbudzuje dojem postrácaných predmetov. Počtom a zložením (ojedinelé bronzové ihlice, bronzové krúžky, odlievaný terčík/nášivka s uškom, hroty šípov) $\mathrm{v}$ podstate kopíruje fond získaný pri archeologických výskumoch v rokoch 1964-1990.

3. Úplne novou zložkou dokladov osídlenia Pohanskej v mladšej a neskorej dobe bronzovej sú depoty „z blízkeho areálu“ na severozápadnom svahu pod akropolou i zo "širšieho zázemia“ v časti Báborská. Koniec dvadsiateho a začiatok dvadsiateho prvého storočia priniesol mimoriadny početný nárast tejto kategórie nálezov. Ukázalo sa, že v mladšej a neskorej dobe bronzovej sú na západe strednej Európy, v Karpatskej kotline i v oblasti rozšírenia lužickej kultúry na Slovensku hromadné nálezy viazané na sídla, často opevnené (Huth 2016, 221; Szabó 2016, 165; Veliačik 2004, 57, obr. 1).

Na základe časového zaradenia súborov je zrejmé, že praktiky deponovania realizovali na lokalite Plavecké Podhradie Pohanská v závere stredných a predovšetkým $\mathrm{v}$ priebehu mladších popolnicových polí. Zloženie a materiál depotov neodpovedá predstavám o obyvateloch hradiska získaných na základe skromných sídliskových nálezov. Skôr sa zdá, že k nim patrili aj elity disponujúce kontaktmi do vzdialených oblastí, zručnostami a nástrojmi potrebnými na produkciu prestížnych výrobkov, ako aj prístupom k vzácnym surovinám. 


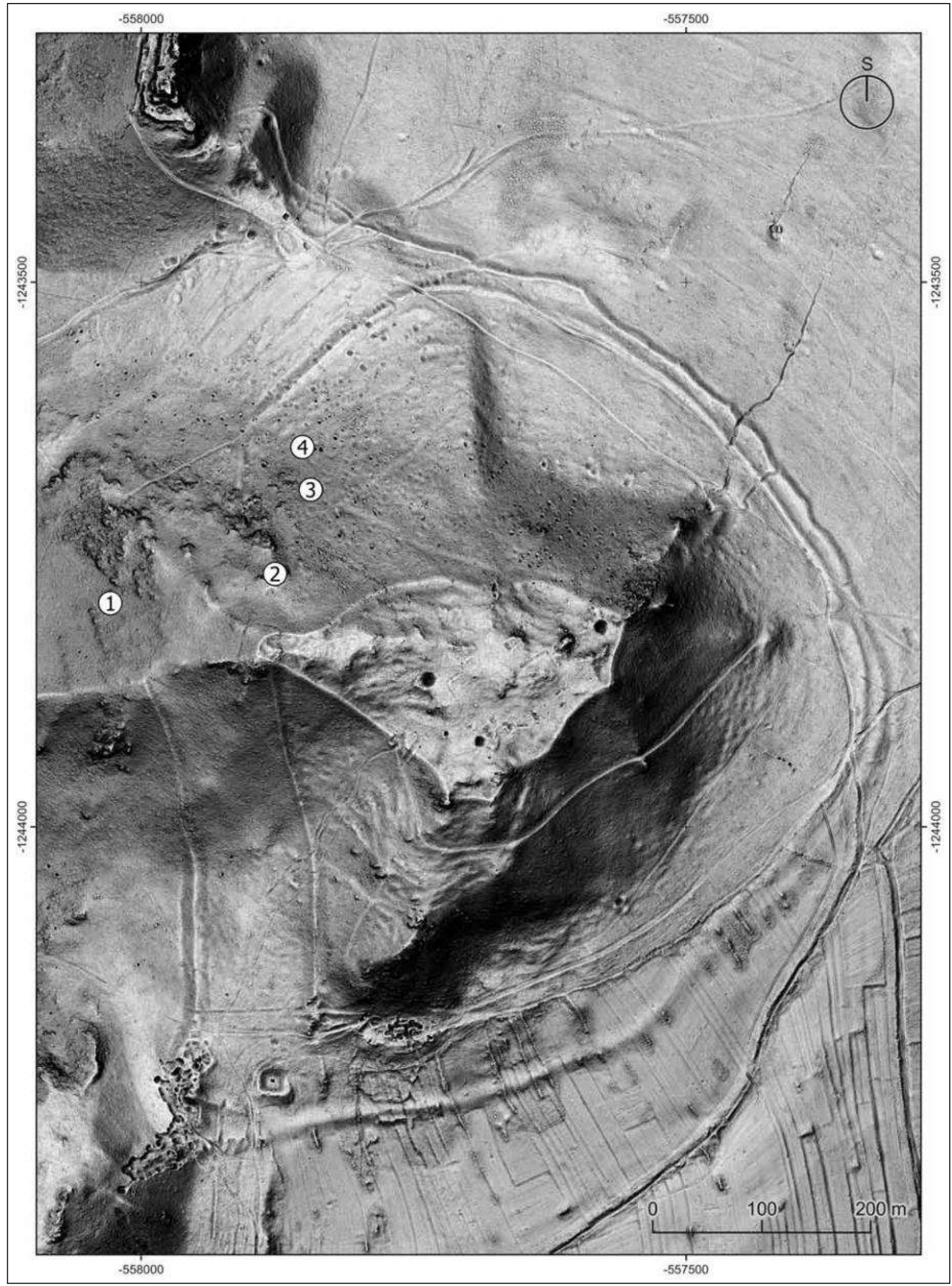

Tab. I. Plavecké Podhradie-Pohanská. Digitálny model reliéfu s vyznačenými miestami zameraných nálezov. 1 - Plavecké Podhradie III; 2 - Plavecké Podhradie I; 3 - Plavecké Podhradie IV; 4 - miesto nálezu železného nákrčníka. Zdroj produktu LLS: ÚGKK SR. 


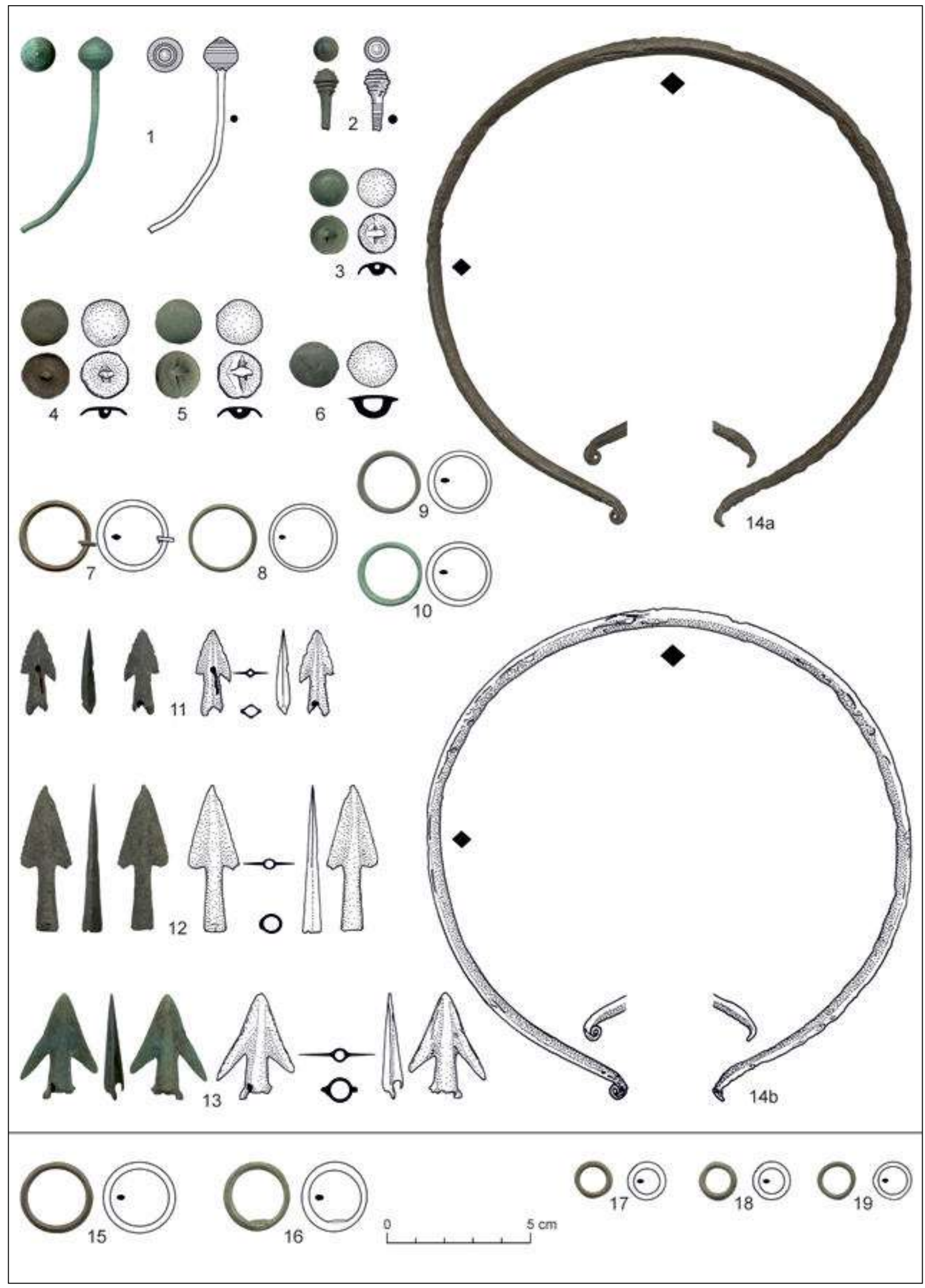

Tab. II. Plavecké Podhradie-Pohanská. 1-14 - ojedinelé nálezy; 15-19 - súčast’ hromadného nálezu zlatých náramkov Plavecké Podhradie IV. 


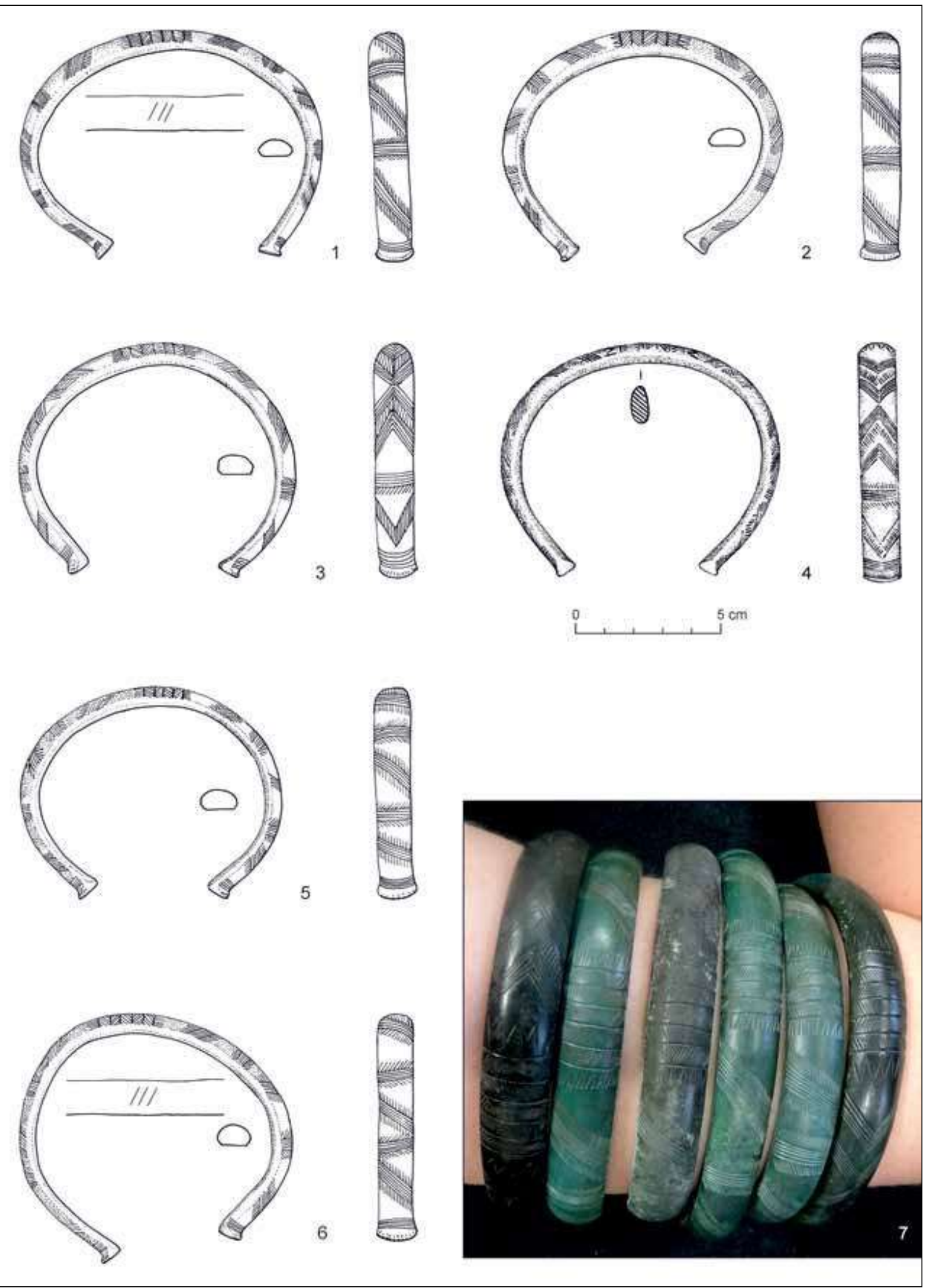

Tab. III. Plavecké Podhradie-Pohanská. Hromadný nález Plavecké Podhradie I. 


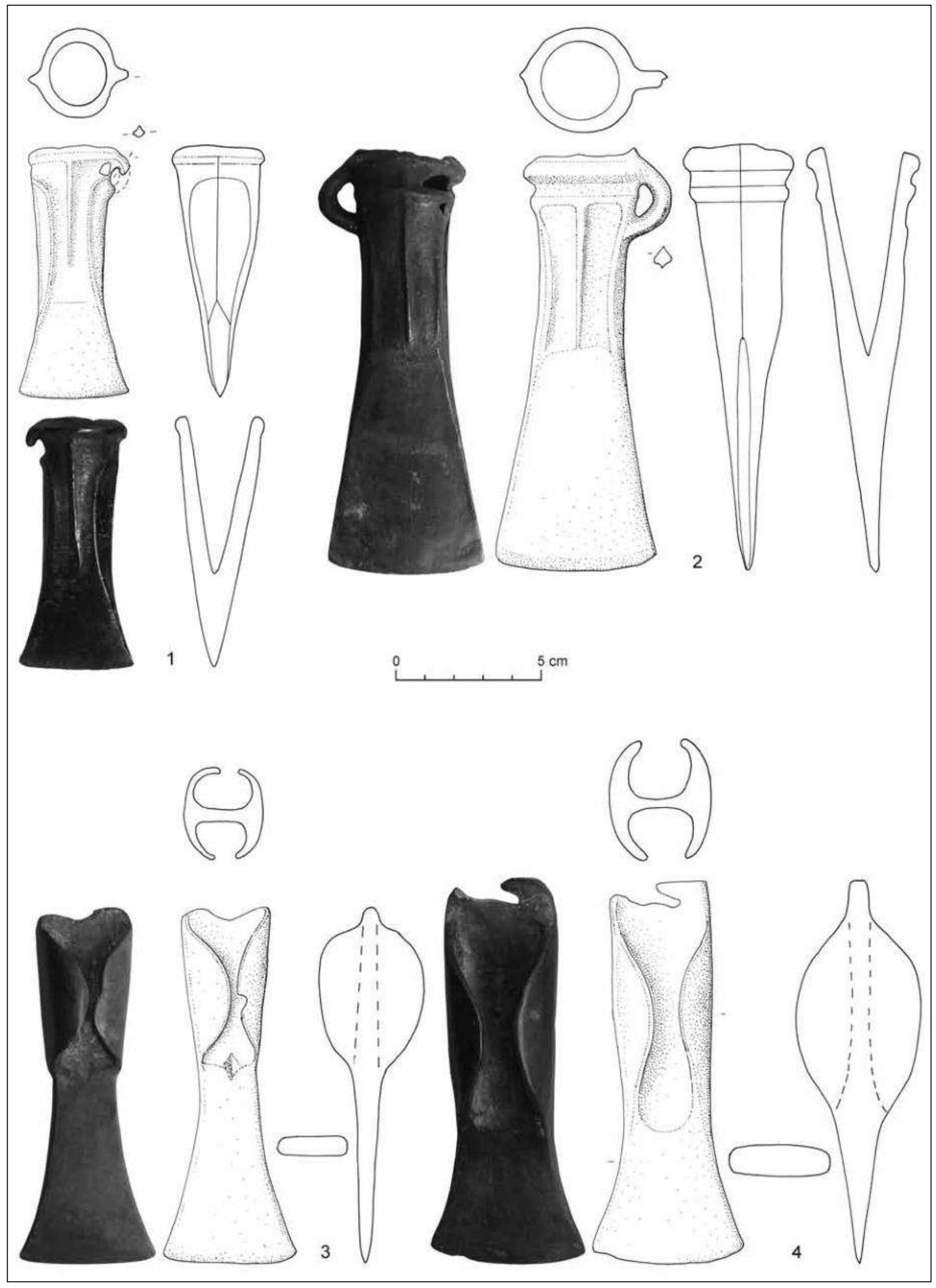

Tab. IV. Plavecké Podhradie-Pohanská. Hromadný nález Plavecké Podhradie II. 


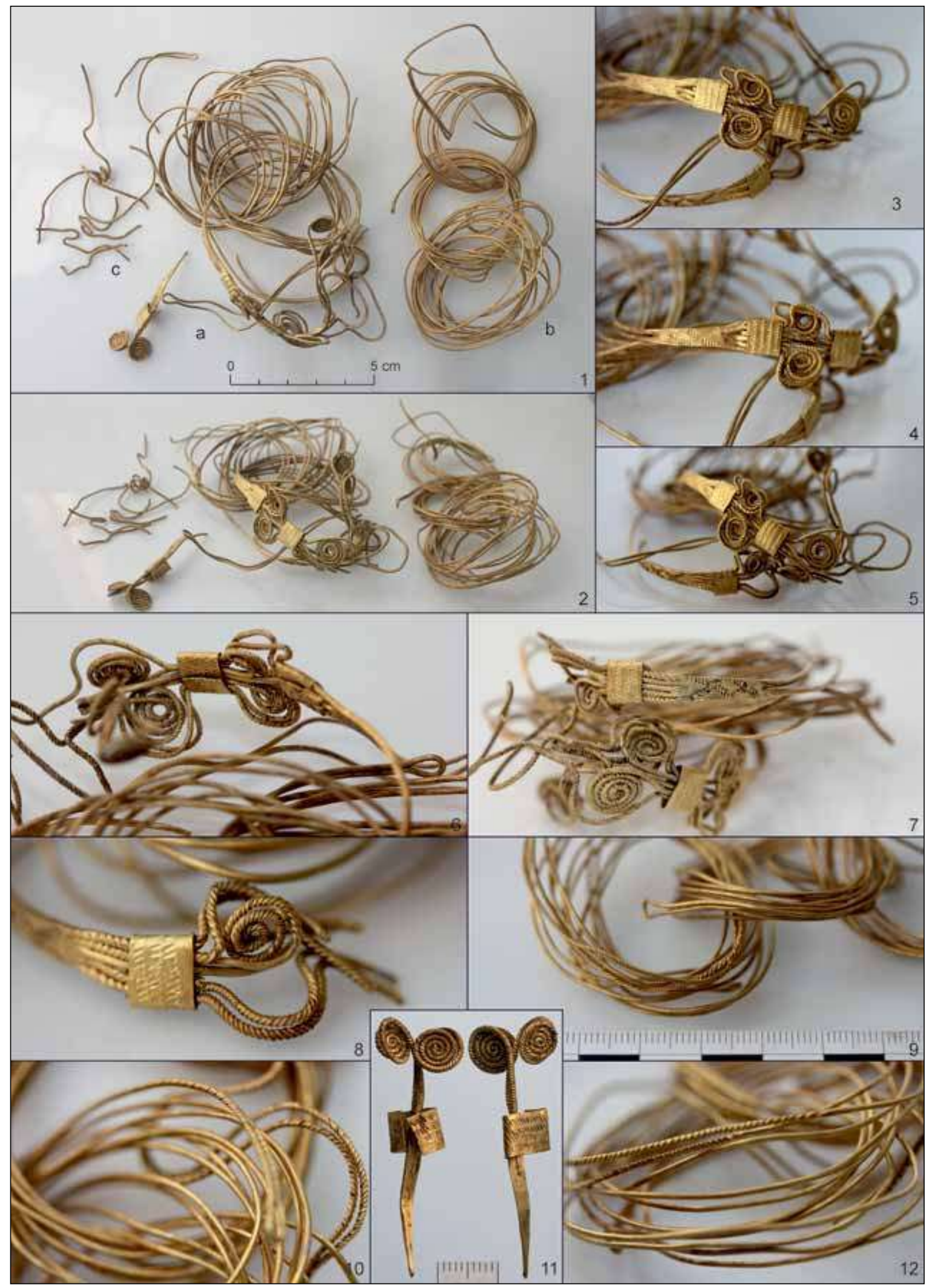

Tab. V. Plavecké Podhradie-Pohanská. Hromadný nález Plavecké Podhradie IV. 


\section{LITERATÚRA}

Bartík 2002 - J. Bartík: Gold bracelet from Middle Slovakia. Anodos. Studies of the Ancient World 2, 2002, $29,30$.

Bartík/Čambal 2018 - J. Bartík/R. Čambal: Pár výzdobných puncov z Pohanskej pri Plaveckom Podhradí. Zborník SNM 112. Archeológia 28, 2018, 115-125.

Bartík/Farkaš/Jelínek 2019 - J. Bartík/Z. Farkaš/P. Jelínek: Bronzehortfunde aus den Kleinen Karpaten und ihren Vorgebirgsgebieten. In: I. Bazovský/G. Březinová (ed.): L’udia a hory-archeologická perspektíva. Interakcie l'udských spoločenstiev horských a podhorských oblastí. Zborník SNM. Archeológia. Supplementum 12. Bratislava 2019, 15-102.

Bobek/Elschek 2020 - P. Bobek/K. Elschek: Nálezy bronzových predmetov zo sídliska v Zohore, poloha Piesky. In: V. Mitáš/O. Oždáni (ed.): Zborník príspevkov z XV. medzinárodnej konferencie Doba popolnicových polí a doba halštatská Smolenice 15.-19. október 2018. Nitra 2020, 35-52.

Eisner 1933 - J. Eisner: Slovensko v pravěku. Bratislava 1933.

Gruber 2008 - H. Gruber: Schätze aus Gold. Die urnenfelderzeitlichen Depotfunde vom Arikogel und aus dem Koppental. In: Schätze-Gräber-Opferplätze. Archäologie im Salzkammergut. Fundberichte aus Österreich. Materialheft A6. Wien 2008, 72-77.

Hansen 1994 -S. Hansen: Studien zu den Metalldeponierungen während der älteren Urnenfelderzeit zwischen Rhônetal und Karpatenbecken. UPA 21. Bonn 1994.

Huth 2016 - Ch. Huth: Metallfunde in urnenfelderzeitlichen Höhensiedlungen Mitteleuropas. In: H. Baitinger (Hrsg.): Materielle Kultur und Identität im Spannungsfeld zwischen Mediterraner Welt und Mitteleuropa. Mainz 2016, 221-237.

Janšák 1928 - Š. Janšák: Niektoré novoobjavené hradiská slovenské. Sborník Muzeálnej slovenskej spoločnosti 22, 1928, 4-9.

Kemenczei 1999 - T. Kemenczei: Spätbronzezeitliche Goldschatzfunde. In: T. Kovács/P. Raczki (Hrsg.): Prähistorische Goldschätze aus dem Ungarischen Nationalmuseum. Budapest 1999, 63-79.

Kytlicová 2007 - O. Kytlicová: Jungbronzezeitliche Hortfunde in Böhmen. PBF XX/12. Stuttgart 2007.

Lehrberger a i. 1997 - G. Lehrberger/J. Fridrich/R. Gebhard/ J. Hrala: Das prähistorische Gold in Bayern, Böhmen und Mähren: Herkunft - Technologie - Funde. Band I: Textband. Band II: Katalog/Tafeln. Band III: Karten. Památky archeologické. Supplementum 7. Praha 1997.

Leitmannová/Gálová/Michalík 2020 - K. Leitmannová/ L. Gálová/L'. Michalík: Projekt leteckého a laserového skenovania SR a tvorby digitálneho modelu reliéfu. In: J. Weigel/A. Berková (ed.): Družicové metódy v geodézii a katastru. Brno 2020, 74-78.

Malček 2006 - R. Malček: Výsledky zistovacieho výskumu vo Zvolene na Borovej hore. Zborník SNM 100. Archeológia 16, 2006, 55-70.

Mayer 1977 - E.-F. Mayer: Die Äxte und Beile in Österreich. PBF IX/9. München 1977.

Mozsolics 1981 - A. Mozsolics: Der Goldfund von Várvölgy-Felsőzsid. In: H. Lorenz (Hrsg.): Studien zur Bronzezeit. Festschrift für W. A. von Brunn. Mainz 1981, 299-308.

Mozsolics 2000 - A. Mozsolics: Bronzefunde aus Ungarn. Depotfundhorizonte Hajdúböszörmény, Románd und Bükkszentlászló. Kiel 2000.
Novotná 1970 - M. Novotná: Die Äxte und Beile in der Slowakei. PBF IX/3. München 1970.

Novotná 1984 - M. Novotná: Halsringe und Diademe in der Slowakei. PBF XI/4. München 1984.

Pabst 2013 - S. Pabst: Transalpine Verbindungen im typologischen Beziehungsgeflecht ältereisenzeitlicher Brillenfibeln. Archaeologia Austriaca 94, 2013, 27-56.

Pare 2004 - Ch. F. E. Pare: Schwert, Hallstattzeit. In: H. Beck/D. Geuenich/H. Steuer (Hrsg.): Reallexikon der Germanischen Altertumskunde. Band 27. Berlin - New York 2004, 523-545.

Parma 2004 -D. Parma: Sídlištní pohřby z Ivanovic na Hané. In: O. Chvojka (ed.): Popelnicová pole a doba halštatská. Archeologické výzkumy v jižních Čechách. Supplementum 1. České Budějovice 2004, 429-450.

Parma a kol. 2017 -D. Parma a kol.: Archeologie střední a mladší doby bronzové na Vyškovsku. Brno 2017.

Paulík 1971 - J. Paulík: Kultový nález na hradisku z mladšej doby bronzovej v Plaveckom Podhradí. Musaica 22 (11), 1971, 31-39.

Paulík 1976 - J. Paulík: Keltské hradisko Pohanská v Plaveckom Podhradí. Bratislava 1976.

Pieta 1971 - K. Pieta: Nové sídliskové nálezy z okolia Plaveckého Podhradia. Zborník Záhorského múzea v Skalici 2, 1971, 5-7.

Rebay 2006 - K. C. Rebay: Das hallstattzeitliche Gräberfeld von Statzendorf in Niederösterreich. Möglichkeiten und Grenzen der Interpretation von Sozialindexberechnungen. UPA 135. Bonn 2006.

Řihovský 1979 - J. Ǩíhovský: Die Nadeln in Mähren und im Ostalpengebiet. PBF XIII/5. München 1979.

Říhovský 1992 - J. Ř́íhovský: Die Äxte, Beile, Meissel und Hämmer in Mähren. PBF IX/17. Stuttgart 1992.

Říhovský 1996 - J. Říhovský: Die Lanzen-, Speer- und Pfeilspitzen in Mähren. PBF V/2. Stuttgart 1996.

Salaš 2005 - M. Salaš: Bronzové depoty střední až pozdní doby bronzové na Moravě a v Slezsku. Brno 2005.

Stuchlík 2015 - S. Stuchlík: Zlato v období popelnicových polí na Moravě a ve Slezsku. In: O. Oždáni (ed.): Popolnicové polia a doba halštatská. Zborník referátov z XII. medzinárodnej konferencie „Doba popolnicových polí a doba halštatská". Nitra 2015, 235-244.

Szabó 2016 - G. Szabó: Hortfunde und Siedlungen. Neue Fakten zum Kontext der spätbronzezeitlichen Deponierungen in Ungarn. In: S. Hansen/D. Neumann/T. Vachta (Hrsg.): Raum, Gabe und Erinnerung. Weihgaben und Heiligtümer in prähistorischen und antiken Gesellschaften. Berlin Studies of the Ancient World 38. Berlin 2016, 165-209.

Tomčíková/Paulík 2004 - K. Tomčíková/J. Paulík: Archeologický výskum na Pohanskej v Plaveckom Podhradí roku 1990. Zborník SNM 98. Archeológia 14, 2004, 43-66.

Tomčíková/Paulík 2006 - K. Tomčíková/J. Paulík: Archeologický výskum na Pohanskej v Plaveckom Podhradí roku 1990 - 2. čast'. Zborník SNM 100. Archeológia 16, 2006, 73-106.

Tomedi 2002 - G. Tomedi: Das hallstattzeitliche Gräberfeld von Frög. Die Altgrabungen von 1883 bis 1892. Archaeolingua. Budapest 2002.

Veliačik 2004 -L. Veliačik: Nové poznatky ku štruktúre hradísk lužickej kultúry na severnom Slovensku. Študijné zvesti Aú SAV 36, 2004, 57-74. 
Rukopis prijatý 21. 8. 2020

Translated by Stephanie Staffen

PhDr. Juraj Bartík, PhD. Slovenské národné múzeum Archeologické múzeum Žižkova 12

P.O.BOX 13

SK - 81006 Bratislava

juraj.bartik@snm.sk

Mgr. Radoslav Čambal, PhD. Slovenské národné múzeum Archeologické múzeum

Žižkova 12

P.O.BOX 13

SK - 81006 Bratislava

radoslav.cambal@snm.sk
Ing. Tibor Lieskovský, PhD.

Katedra globálnej geodézie a geoinformatiky

Stavebná fakulta STU v Bratislave

Radlinského 11

SK - 81005 Bratislava

tibor.lieskovsky@stuba.sk

\title{
Pohanská near Plavecké Podhradie New Information on the Hillfort from the Late Bronze Age
}

\author{
JurajBartík - Radoslav Čambal - Tibor Lieskovský
}

\section{SUMMARY}

Between 1927 and 1990, the Pohanská hillfort in Plavecké Podhradie was repeatedly surveyed (Fig. 1: A, B) and examined using probes. According to the results of the research, in the Late Bronze Age settlement was concentrated on the highest part of the hill protected by a rampart with crossed logs and a frontal stone wall, archeologically dated to HA2. It was noted that the settlement finds and evidence of craft production were poor and during the urnfield period the site served as a refuge. Fragments of clay vessels were classified into the time period of $\mathrm{BD} /$ HA1-HB1 and mainly attributed to the Čaka, Velatice and Podolie cultures (Paulík 1971, 31; 1976, 128; Pieta 1971, 5; Tomčíková/Paulík 2006, 73).

After 2019, the results of laser scanning provided fundamentally more precise information on the morphology of the site and on the course of the rampart. The fortification on the top of the hill protected an area of

Fig. 1. Plavecké Podhradie-Pohanská. Plans of the course of the ramparts (A - after Janšák 1928, 3, fig. 1; B - after Paulík 1976, appendix 2).

Fig. 2. Plavecké Podhradie-Pohanská. One-off finds.

Fig. 3. Plavecké Podhradie-Pohanská. Hoard Plavecké Podhradie III.

Pl. I. Plavecké Podhradie-Pohanská. A digital model of the relief indicating the places where surveyed finds were found. 1-Plavecké Podhradie III; 2-Plavecké Podhradie
$3.92 \mathrm{ha}$, on the northern slope under the acropolis, a path leading to a source was identified (Pl. I). The collection has also experienced significant growth. As a result of illegal activities, one-off finds (Fig. 2; Pl. II: 1-14) and four hoards have been added. Three are composed of bronze artefacts (Fig. 3; Pl. III; IV) and the fourth of gold (Pl. V) artefacts, and originate from 'the nearby grounds' on the slope under the fortification and from the 'wider area' of the hillfort (Pl. I). The new finds confirm that the main period of settlement in this site in the Bronze Age was the middle and later Urnfield Period (HA2 and HB1). The composition and material of the hoards does not match ideas of the inhabitants of the hillfort based on the modest settlement finds. It appears instead that they also had an elite with contacts in far-away places, the skills and tools necessary for producing prestige products and access to precious raw materials.

I; 3-Plavecké Podhradie IV; 4 - site of the find of an iron neck-ring. Source of the LLS product: ÚGKK SR.

Pl. II. Plavecké Podhradie-Pohanská. 1-14 - one-off finds; 15-19 - part of a hoard of gold bracelets Plavecké Podhradie IV.

Pl. III. Plavecké Podhradie-Pohanská. Hoard Plavecké Podhradie I.

Pl. IV. Plavecké Podhradie-Pohanská. Hoard Plavecké Podhradie II.

Pl. V. Plavecké Podhradie-Pohanská. Hoard Plavecké Podhradie IV. 